Portland State University

PDXScholar

Fall 1988

\title{
Infrastructure politics: the dynamics of crossing San Francisco Bay
}

Sy Adler

Portland State University

Follow this and additional works at: https://pdxscholar.library.pdx.edu/usp_fac

Part of the Urban Studies and Planning Commons

Let us know how access to this document benefits you.

\section{Citation Details}

Adler, Sy. "Infrastructure Politics: The Dynamics of Crossing San Francisco Bay." The Public Historian 10.4 (1988): 19-41.

This Article is brought to you for free and open access. It has been accepted for inclusion in Urban Studies and Planning Faculty Publications and Presentations by an authorized administrator of PDXScholar. Please contact us if we can make this document more accessible: pdxscholar@pdx.edu. 


\title{
Infrastructure Politics: The Dynamics of Crossing San Francisco Bay
}

\author{
Sy AdLER
}

\section{Introduction}

In 1945 it was obvious to virtually everyone in the San Francisco Bay Area that the San Francisco-Oakland Bay Bridge would soon be hopelessly congested. Opened to motor vehicle traffic in 1936, the bridge was a huge traffic and financial success. Financing for this monumental public work was provided by Herbert Hoover's Reconstruction Finance Corporation (RFC), which bought the first $\$ 62$ million of toll-secured revenue bonds in late 1932. The project was one of Hoover's personal favorites. The Great Engineer had been associated with the location studies done for the bridge in the late 1920s. Because it was one of RFC's earliest and largest efforts to create employment during the darkest depression days, the president hoped it would prove a political as well as an engineering triumph. ${ }^{1}$

The history of efforts to deal with the Bay Bridge problem provides case material for developing a theory of the politics of transport infrastructure projects. There are two primary analytical dimensions. One is the influence of urban rivalry on all aspects of infrastructure planning and implementation. The second concerns the circumstances that permit rivalryinduced political stalemates to be broken.

1. Hoover-Young San Francisco Bay Bridge Commission, Report (1930), n.p; J. Olson, Herbert Hoover and the Reconstruction Finance Corporation, 1931-1933 (Ames: Iowa State University Press, 1977). 


\section{Urban Rivalry and Infrastructure Politics}

As Christine Rosen notes in a study of nineteenth-century urban public works, "infrastructural development, by its very nature, usually benefited some people more than others or benefited some people while hurting others." 2 The inherently uneven distribution of project benefits, particularly those of transport projects, across space and over time creates location advantages for some places and disadvantages others. Since capital in the United States is mobile, places are continuously competing with one another to maintain and attract capital investment. This basic feature of the U.S. urban development process often gives rise, therefore, to coalitions of place-rooted investors, which form to defend and advance local interests. Infrastructure projects are inevitably strategic weapons in the hands of these coalitions, which seek to deploy them in order to gain location advantages. Competing coalitions try to use infrastructure projects to shape development, rather than simply to respond to existing demand forces. ${ }^{3}$

Urban rivalry, then, produces controversy regarding all aspects of project planning and implementation. The most controversial projects are metropolitan-scale facilities that will concentrate benefits in one place or in a small number of places that are jointly pursuing location advantage. Given the relative responsiveness of political structures at all United States government levels to local concerns, controversy may produce stalemate, as local coalitions within the same metropolitan region collide in their efforts to defend and advance their interests.

\section{Transcending Stalemate}

This study analyzes the possibilities and limits of three ways around stalemate. One is through consensus-building. Consensus is achievable if individual projects can be designed and financed in a disaggregated way, both spatially and temporally, so that the development aspirations of many competing places can be served. The contents of the package reflect the relative political strengths of the participants in the process. Classical pork barrel politics are a species of consensus-building.

The second way around stalemate is through a claim of political and military priority public interest which can be used either to support a

2. C. Rosen, "Infrastructural Improvement in Nineteenth-Century Cities: A Conceptual Framework and Cases," Journal of Urban History 12 (May 1986), 249.

3. N. Fainstein and S. Fainstein, "Regime Strategies, Communal Resistance, and Economic Forces," in S. Fainstein, N. Fainstein, R. Hill, D. Judd, and M. Smith, Restructuring the City (New York: Longman, 1983), 245-82; D. Harvey, "The Place of Urban Politics in the Geography of Uneven Capitalist Development," in D. Harvey, The Urbanization of Capital (Baltimore: The John Hopkins University Press, 1985), 125-64; P. Peterson, City Limits (Chicago: University of Chicago Press, 1981). 
project or to oppose one advanced by a competitor. Such a claim aims at silencing opposition, thereby protecting projects from challenge by disadvantaged coalitions. The argument is straightforward: projects that will contribute substantially to political and economic stability or military preparedness must override narrow, self-interested concerns of individual localities. In the public works field, political and military claims have historically been crucial in legitimating government action. The French national government saw fit to subsidize Haussmann's reconstruction of central Paris primarily because of such considerations, and public works spending has since been linked with governmental concern over unemployment-caused political instability. ${ }^{4}$ Ironically, project sponsors have often been constrained as a result of this linkage, coming into conflict with government officials seeking to regulate public works spending solely in relation to stabilization concerns.

The third way around stalemate is through access to financial capital. Haussmann, once again, worked closely with Parisian financiers, and Robert Moses forged long-lasting alliances with New York bond market participants. ${ }^{5}$ Like a claim of political or military priority, an access claim serves to protect particular projects from challenges brought by competitors. The relatively autonomous governmental agencies often created to finance and build infrastructure, utilized by Moses and others to great advantage, further reinforce the protection enjoyed by favored projects.

All three of these ways around stalemate were tried during the thirteenyear-long effort to deal with Bay Bridge congestion. Consensus-building was the objective of the Bay Area Council (BAC), the regional corporateelite policy planning group. BAC was formed in an effort to get the region's big business leadership to organize itself for the competitive struggle ahead. As Francis V. Keesling, chairman of BAC's executive committee told a conference discussing peacetime reconversion issues, "What we are trying to do is to solidify the Bay Area against the inroads which Los Angeles might make. We want to protect ourselves against the activities of the South, and I take my hat off to them for they are certainly doing a job." BAC was the only functioning regional organization in the Bay Area, with committees operating in each of the nine counties comprising the region. ${ }^{6}$

Traffic and transportation issues were crucial for the council. It saw a need for huge amounts of transportation infrastructure to accomodate Bay Area population and economic growth. The concern was that insufficient

4. J. Garraty, Unemployment in History (New York: Harper and Row, 1978); A. Sutcliffe, The Autumn of Central Paris (London: Edward Arnold, 1970).

5. D. Harvey, "Paris, 1850-1870," in D. Harvey, Consciousness and the Urban Experience (Baltimore: The John Hopkins University Press, 1985), 63-220; A. Walsh, The Public's Business: The Politics and Practices of Government Corporations (Cambridge: MIT Press, 1978).

6. F.V. Keesling Papers, Box 21, Folder 183, 10/17/45. Stanford University Library; M. Scott, The San Francisco Bay Area (Berkeley: University of California Press, 1959). 
transport capacity would "strangle" the region, "choking off" potential growth, driving business elsewhere, and causing the regional economy to "stagnate" and then decline. BAC developed numerous plans and proposals intended to generate consensus regarding united region-wide action.

During the cold war 1940s and 1950s rival places filled the air with political and military priority claims, continuing a strategy that Bay Area place-coalitions had developed following World War I. Roger Lotchin notes that the Bay Area emerged as a metropolitan-military complex in the 1920s, as the region sought military resources in order to stimulate regional economic growth. Lotchin emphasizes rivalry between San Francisco and Los Angeles as the spur to Bay Area militarization, a strategy that virtually all organized groups in San Francisco supported. At the same time, the navy was suffering in inter-service rivalries, and was seeking civilian friends. During this period the Bay Area learned to trumpet the defense rationale in order to unify the region and to generate support for increased military spending. ${ }^{7}$

The downtown San Francisco financial community played a central role in the infrastructure planning process. Annmarie Walsh notes that "the principles of the bond market insist that financial considerations should determine policy." An important consequence of this central role played by private financial capital, Walsh argues, is that highway projects are favored over commuter rail transportation, because of the profitability of the former and the fiscal incapacity of the latter. ${ }^{8}$ Finance capital institutions, however, have both a general interest in underwriting infrastructure projects, as well as investments rooted in particular places. Walsh doesn't attribute spatial concerns to bond market participants that might be reflected in support for rail rapid transit. In the Bay Area, downtown San Francisco financiers chose to grant access to a metropolitan-scale commuter rail project-Bay Area Rapid Transit (BART)—rather than to a bridge/highway facility in order to deal with Bay Bridge congestion. While this particular way around stalemate was eventually the one charted, it was as controversial as the others. A unified regional program for the Bay Area remained highly problematic.

\section{Bay Area Rivalries and San Francisco Bay Crossings}

The original Bay Bridge project was handled by RFC's Self-Liquidating Division. RFC was interested in financing only those projects which were certain not to default on their interest and principal payments. Insistence on financial soundness flowed directly from RFC's orientation as primarily a banker's organization. ${ }^{9}$ It demanded several conditions intended to

7. R. Lotchin, "The City and the Sword: San Francisco and the Rise of the MetropolitanMilitary Complex 1919-1941," Journal of American History 65 (March 1979), 996-1020.

8. A. Walsh, The Public's Business, 338.

9. J. Olson, Herbert Hoover and the Reconstruction Finance Corporation. 
minimize and protect the federal government's financial commitment. Among these were requirements that the California legislature vote the funds for building the approaches to the bridge and also approve paying the operating, maintenance, and insurance costs for the structure out of state highway funds rather than from tolls. ${ }^{10}$

The state legislature reluctantly agreed to these terms, but the resulting combination of state and federal fiscal conservatism caused the construction of a more cramped Bay Bridge than a less cautious financial arrangement might have allowed. Approaches to the structure were very limited on both the San Francisco and East Bay sides, and the traffic lanes on the bridge were narrow. The double-decked span carried automobile traffic on the upper level. The lower deck carried commercial vehicles and the Bridge Railway, which consisted of two sets of tracks running directly into a Transbay Transit Terminal located on the fringe of the San Francisco central business district. ${ }^{11}$

Bridge rail patronage was, however, very disappointing, falling well below expectations. Designed to carry fifty million people per year, and seventeen thousand during the peak twenty-minute period, in 1941 the rails handled just fourteen million. Even during the war, when automobile traffic was constrained, twenty-seven million were transported during the peak year of 1945, just fifty-four percent of capacity. In only one year, 1945, were Bridge Railway toll revenues sufficient to meet even the interest costs on the rail portion of the bridge, necessitating a subsidy from auto users. ${ }^{12}$

In October 1945, the California Toll Bridge Authority (CTBA), the state-created agency that built and managed the structure, approved a study to be made by the Department of Public Works (DPW) of an additional crossing of San Francisco Bay. The CTBA action was supported and encouraged by numerous business, labor, and civic groups, led by the recently created Bay Area Council. ${ }^{13}$

The main protagonists on the bay crossing issue were the cities of San Francisco and Oakland, although the rest of the region would become involved in the conflict. There were two major points of contention. First, San Francisco wanted to see mainline transcontinental railroad tracks included on the next crossing. A low-level structure would be required to support mainline trains at acceptable grades. The major rail freight and

10. California Division of San Francisco Bay Toll Crossings (hereafter SBTC), A Report to Department of Public Works on Additional Toll Crossings of San Francisco Bay, 1948, n.p; California Toll Bridge Authority (hereafter CTBA), Transcript of meeting, November 27, 1951. California State Archive, Sacramento.

11. SBTC, A Report to Department of Public Works on Additional Toll Crossings of San Francisco Bay; California Railroad Commission, Report on Survey of Interurban Passenger Transportation Between San Francisco and East Bay Cities via the San Francisco-Oakland Bay Bridge, Volume 4, Part 1, 1941, n.p.

12. SBTC, A Report to Department of Public Works on Additional Toll Crossings of San Francisco Bay.

13. CTBA, Transcript of Meeting, October 3, 1945. 
passenger terminals were on the Oakland side of the bay; San Francisco business, labor, and political leaders wanted to bring rail traffic directly into the city. Downtown Oakland leaders opposed this effort to divert traffic. Downtown Oakland saw the central issue as the immediate relief of existing motor vehicle traffic congestion. A high-level structure near the Bay Bridge in the established transbay travel corridor appeared to offer the best prospect of accomplishing this goal.

San Francisco argued this was too narrow a view, reflecting short-term thinking. The need was for long-term planning to accommodate future Bay Area growth. Industry and people were moving south, down the peninsula and into southern Alameda County. (Oakland was in northern Alameda County.) The goals of relieving congestion on the existing bridge and serving future development, San Francisco claimed, would best be served by a crossing in a location several miles south of the present bridgeheads. Such a southerly location would also provide the conditions necessary for a railroad-supporting low-level structure. Moreover, since the existing Bay Bridge approaches were limited, traffic entering San Francisco from the East Bay was soon flowing on the city streets, as was traffic heading from the peninsula to the northeast. If a southern crossing were available then this through traffic could be removed from the streets, freeing the space for central city-oriented movements.

The San Francisco Labor Council consistently supported a southern crossing, reflecting a concern with the future of industrial production within the city. Manufacturing firms were concentrated along the city's bayshore in the vicinity of a southern crossing. A southern crossing would facilitate freight transport between San Francisco's manufacturing district and related firms in the East Bay, as well as improve travel conditions between working-class residential areas in the southeastern sector of the city and industrial production zones in southern Alameda County.

San Francisco officials were also deeply concerned with the possible negative impacts of a parallel bridge on downtown traffic problems. The two bridges would channel an increasing volume of traffic through the city's central core. Technical and political leaders argued that an elaborate and extremely expensive network of approach and downtown freeway distribution structures would be required to protect downtown streets from paralyzing congestion. The city leadership was distressed at the prospect of locally financing these expensive structures. The East Bay would not likely favor including these costly structures as part of the bridge project. DPW would also likely be concerned with the effect of including the structures on the project's financial feasibility. ${ }^{14}$

Oakland sought to protect its competitive position as a regional center

14. Citizens Postwar Planning Committee, Report to Mayor Roger Lapham, 1945, n.p.; E.E. Robinson, The Case for the Southern Crossing, Brief of testimony introduced before the Assembly Committee on Tidelands and Related Problems at its hearing in Sacramento, 1949, n.p; San Francisco Board of Supervisors, Journal, February 11, 1946. 
and to secure its dominant position in the East Bay against San Francisco designs. Oakland wanted southern Alameda County's growing population to focus on Oakland, not San Francisco. Another bridge in the existing transbay traffic corridor would facilitate further residential development in those parts of Alameda and Contra Costa Counties close to Oakland. Perhaps many of these people would commute to San Francisco to work, but Oakland would be closer for shopping and other activities.

The dynamics of political and military claims: Part I (1949-1952). San Francisco leaders were concerned that DPW shared the Oakland view that the only legitimate issue involved was the immediate relief of existing bridge traffic congestion. ${ }^{15}$ Therefore, San Francisco asked one of its U.S. congressional representatives to seek a study by the national military establishment.

In March 1946, Richard Welch introduced a measure in the House Naval Affairs Committee to have the Navy and War Departments take up the problem. In 1941 Welch had unsuccessfully sought a southern crossing as a civil defense measure in order to evacuate the city. ${ }^{16}$ In April the full House approved a resolution creating a Joint Army-Navy Investigative Board (JANB). The navy was cool to the subject. The military had studied the question of additional crossings in 1941 and concluded that increased capacity was not necessary for defense purposes. President Truman, however, was said to be favorably disposed to the study. Congressman Welch told an appreciative San Francisco Board of Supervisors that any plan for a second crossing should include railroad tracks. Oakland Mayor Herbert Beach condemned Welch, saying he would oppose any low-level structure that would blockade the Oakland Port. The Oakland Chamber of Commerce stood behind their mayor, attacking this blatant move to steer traffic into San Francisco. ${ }^{17}$

The Joint Army-Navy Board came to the Bay Area to conduct public hearings during the summer of 1946. The San Francisco delegation to the board was led by Supervisor Marvin Lewis, who had staked out the transportation area as one of his main governmental concerns. The San Francisco supervisors sent Lewis to the board hearings armed with a unanimously adopted Lewis-sponsored resolution stating that the best interests of San Francisco called for a mainline railroad connection to a Union Depot over any second bay crossing. Lewis reported back how proud he was that San Francisco had been able to present a united front on the need for trains; downtown interests, labor groups, and improvement clubs all supported the position. Lewis also noted Oakland's expressed opposition.

15. San Francisco Chronicle, April 2, 1946; San Francisco News, May 2, 1946.

16. R. Lotchin, "The City and the Sword: San Francisco and the Rise of the Metropolitan-Military Complex 1919-1941."

17. Berkeley Gazette, March 15, 1946; San Francisco Daily Commercial News, May 1, 1946; Alameda Times, June 1, 1946. 
Alliance possibilities were emerging on the issue, however. Cities in southern Alameda County were breaking with Oakland on the bridge location question, and agreeing with San Francisco on the advantages of a southern crossing. Moreover, San Mateo County was likewise interested in additional transport capacity closer to San Mateo. The Oakland-supported crossing would be less desirable for peninsula cities, so they were lining up with San Francisco as well. ${ }^{18}$

On January 25, 1947, JANB reported its findings. The board proposed the immediate construction of a southern crossing of San Francisco Bay, but found there wasn't any need for railroad tracks on the structure. The board had directly questioned the major rail carriers on this question. They had all unequivocally denied any interest in extending their passenger facilities in the Bay Area. The board agreed that a southern location would best facilitate future regional growth. They also noted that while there wasn't any need for an additional crossing from a national defense standpoint, security precautions dictated that bridge structures be dispersed to decrease their vulnerability to enemy attack. The military engineers also pointed out that a parallel crossing close to the existing one would have a harmful effect on downtown San Francisco, worsening traffic congestion there. This was crucial because the relative ability of crossings to enable peak hour commuters to get into and out of the San Francisco central business district was a major location criterion.

The Army-Navy Board surprised everyone with a companion recommendation to its call for a southern crossing. They broadened their field of vision to consider transit issues in relation to motor vehicle traffic and told the Bay Area that it would be impossible continually to construct highway crossings and related parking facilities. At some point automotive congestion would become so severe that the area would be forced to increase its use of transit. The board proposed that the Bay Area begin to plan now for this eventuality. They noted that extensive rail capacity was already available, but was seriously underutilized. This, the board argued, was because the existing service, supplied by the privately-owned Key System, was very poor. The solution was a fully integrated rail rapid transit service using grade-separated exclusive rights-of-way in San Francisco and the East Bay, and an underwater tube to make the connection. The board even went so far as to consult with various tunnel and other transit engineering experts on a tentative plan of routes and estimated costs for such a rail system. The total cost came in at $\$ 208$ million, with the centerpiece tube costing $\$ 74$ million. Constructing a tube had an additional benefit:

18. San Francisco Board of Supervisors, Journal, February 11, 1946, July 15, 1946, August 19, 1946; Bay Region Business, August 13, 1946; East Bay Supporters for the Southern Crossing, The Case for the Southern Crossing of San Francisco Bay. Presented to California Toll Bridge Authority, 1946, n.p. 
the existing Bridge Railway could be abandoned and paved, thereby increasing Bay Bridge motor vehicle capacity. ${ }^{19}$

This transit proposal did not create much of an immediate stir, however. San Francisco was pleased with the location decision, but still wanted those transcontinental railroad trains. Oakland was upset at the choice of location. The transit idea receded further into the background when the state Department of Public Works reported its findings just a few days later. DPW recommended immediate construction of an identical bridge parallel to and three hundred feet north of the existing structure. Traffic and revenue studies done for DPW by the consulting firm of Coverdale and Colpitts (who had done the same kinds of studies for the original Bay Bridge project) indicated that this parallel crossing was the most likely to divert enough traffic from the existing bridge to make it a sound financial investment. Moreover, existing rail facilities were considered adequate for transit travel. ${ }^{20}$

The conflicting reports spurred feverish activity all around the bay. In Oakland the City Council, Chamber of Commerce, and Real Estate Board declared their allegiance to the parallel bridge. The southern Alameda County cities organized the Committee for a Southern Crossing over San Francisco Bay and agitated for their choice. San Francisco got Congressman Welch to intervene with the secretaries of the army and navy, asking them to delay their final report until additional studies could be made of the costs of including railroad tracks on a crossing. The Bay Area Council appointed a Transportation and Traffic Committee to attempt reconciliation. Finally, DPW undertook a second look at the issues. ${ }^{21}$

In late August 1947, the secretaries of the army and navy released their final report. They agreed with JANB in all particulars, including the transcontinental railroad question; no train tracks were warranted on a southern crossing. ${ }^{22}$

BAC's Traffic and Transportation Committee dissented, voting 18-6 in favor of a parallel bridge. The majority argued that relief of congestion on the existing bridge was the chief priority, and a parallel bridge would accomplish this more cheaply and effectively than a southern crossing. Regarding the transit proposal, the committee majority pointed out that the cost of the tube alone was estimated at $\$ 74$ million and the total project at $\$ 208$ million. The committee "believed that the difficulties of organizing and financing such a system within the near future would be insurmountable, and in view of the other great needs of the communities

19. Joint Army-Navy Board, An Additional Crossing of San Francisco Bay, 1947, n.p. 20. San Francisco Examiner, February 17, 1947; California Department of Public Works, Preliminary Studies for an Additional Crossing of San Francisco Bay, 1947, n.p.

21. Bay Region Business, February 6, 1947; San Francisco Examiner, February 18, 1947; San Francisco Chronicle, August 28, 1947; Oakland Tribune, September 19, 1947.

22. San Francisco Chronicle, August 28, 1947. 
that it would be better to postpone such an undertaking, at least until such time as existing facilities are overtaxed."23 The BAC Board of Governors, however, refused to take a vote on the recommendations submitted by its Traffic and Transportation Committee. Even though the committee had produced a clear majority, the issues were so intensely controversial that the governors were unable to reconcile the differences. ${ }^{24}$

In October the San Francisco Board of Supervisors adopted the Marvin Lewis resolution calling for the immediate construction of a southern crossing. This was the first time official San Francisco declared itself about the location of the next bridge. Lewis began to couple support for a southern crossing with a call to action on JANB's proposed regional rapid transit system. San Francisco political and technical leaders argued that the combined projects would facilitate the aspirations of downtown financial and merchant capital. An alliance of downtown interests and organized labor could, as well, be cemented. Lewis and several downtown financiers and merchants soon emerged as leading activists in the regional rapid transit movement that would eventually build BART. ${ }^{25}$

In November CTBA declared that its policy would be to build both bridges. DPW was to proceed with plans and right-of-way acquisition for both structures. DPW Director Charles Purcell, chief engineer on the original Bay Bridge project, announced he would appoint a special Bay Toll Crossings Division to recommend which bridge ought to be built first. ${ }^{26}$

In November 1948, Ralph Tudor, chief engineer for the Bay Toll Crossings Division, recommended building the parallel bridge first. He pointed out that traffic and revenue studies done by Coverdale and Colpitts said that the parallel bridge should have priority because more than eighty percent of the vehicles crossing the existing bridge would be served by it, while only twenty percent would be attracted to a southern crossing. ${ }^{27}$

The united front in San Francisco in support of a southern crossing now began to crumble, as the downtown business community switched its allegiance to the parallel bridge. In February 1949, the executive committee of BAC declared for a parallel bridge and notified the governor and CTBA of its stand. Official San Francisco was left with few friends: the San Francisco Labor Council and the newspapers remained loyal. Even these

23. San Francisco Bay Area Council Transportation and Traffic Committee, A Report on Additional Crossings of San Francisco Bay, 1947, n.p.

24. San Francisco Chronicle, September 12, 1947; San Francisco Examiner, September 12, 1947, Oakland Tribune, September 20, 1947.

25. San Francisco Chronicle, October 7, 1947; S. Adler, The Political Economy of Transit in the San Francisco Bay Area, 1945-1963 (Washington, D.C: United States Department of Transportation, 1980).

26. San Francisco Examiner, November 11, 1947.

27. SBTC, A Report to Department of Public Works on Additional Toll Crossings of San Francisco Bay. 
friends were divided, though. They favored a southern location but differed as to exactly where the bridge termini should be. ${ }^{28}$

There seem to be two reasons why the major business organizations changed their minds on the bridge location issue. The more important was that they were never really committed to a southern location. The crucial aspects were the transcontinental trains and a downtown passenger terminal. Only a southern crossing could accommodate trains, so the business community supported a southern crossing. When it became clear there weren't going to be any railroad passengers coming directly downtown, the business groups looked to other short-range alternatives that would increase downtown reception capacity. A parallel bridge appeared more appropriate for this. The other reason was that it looked as if a parallel bridge was going to be built anyway. This was what the state wanted to do; the bridge was a local matter. The military engineers had already said there wasn't a need for another bridge from a national defense standpoint. Moreover, downtown groups and the BAC Committee believed that construction of an underwater transit tube was a very longterm, uncertain prospect, given the cost and current transit dynamics. If additional freeways were necessary to avoid congestion caused by the increased number of motor vehicles in central San Francisco, then, the business groups thought, these ought to be built.

A San Francisco Chronicle writer thought he had found some allies for official San Francisco's cause when the United States House of Representatives Armed Services Committee chairman made correspondence between himself and the secretary of the navy public. Included was a warning from a navy vice-admiral that the parallel bridge "violated the fundamental strategic principle of dispersion." The Chronicle reporter felt the navy was politely trying to tell CTBA to give up the parallel bridge. This message was lost, however, on the California Toll Bridge Authority. A few days later it voted unanimously to construct a parallel crossing of San Francisco Bay. ${ }^{29}$

The parties then shifted to Washington, D.C., where the Bay Area would do battle in Congress over legislation sponsored by U.S. Senator Knowland, who supported a parallel bridge. The Senate Armed Services Committee was the terrain; a parallel bridge would need a permit from the military to establish a bridgehead on military property in the middle of the bay. The parallel bridge forces were led by Bay Area Council executive vice-president and general manager Frank Marsh.

Hearings were held in the nation's capital during July 1949. Parallel bridge supporters tried to convince the senators that this was a strictly

28. San Francisco Examiner, December 4, 1947, December 17, 1947; San Francisco Chronicle, December 6, 1947, March 5, 1949; Oakland Tribune, December 18, 1947, November 25, 1948, December 12, 1948; Oakland Post-Enquirer, February 16, 1949; Bay Region Business, March 17, 1949, March 24, 1949.

29. San Francisco Chronicle, March 21, 1949; San Francisco Examiner, March 24, 1949. 
local issue. Since federal money was not involved, Congress should let California take care of its own location decisions. BAC told the Senate Committee that the fight against the parallel bridge and for the southern crossing was a "self-interested" one by people who wanted to see their property values in the southern part of San Francisco and down the peninsula increased. BAC declared that the general interest in the relief of congestion on the existing bridge must take precedence over any "promotional" projects. The executive vice-president of the San Francisco Chamber of Commerce said that obviously the major business groups in his city that supported the parallel bridge would not be doing so if it would harm their downtown investments. Engineer Ralph Tudor stressed the folly in abandoning the Bridge Railway; who would ever finance construction of an enormously expensive tube? This would result if the parallel bridge were blocked and the southern crossing built, because the Bay Area would still be forced to increase Bay Bridge motor vehicle capacity. Then it was San Francisco Mayor Robinson's turn. ${ }^{30}$

According to the Oakland Tribune, "Mayor Elmer E. Robinson of San Francisco . . . pulled out all the stops from fear to patriotism in an effort to transfer from California to the federal government sole judgment in locating a second crossing of the Bay." ${ }^{31}$ Robinson asked the committee: ${ }^{32}$

Can you envision an emergency happening on the San Francisco peninsula? Can you imagine more than a million and a half human beings trying to jam themselves, their babies and their baby carriages, their birds and their cats and their dogs, their automobiles and on foot, the lame and the halt and the blind, trying to force themselves through a bottleneck in conflict with the military trying to get across this bottleneck to do a job of national defense? Can you envision that scene? That is not what we want in any part of this Nation of ours. That is not what we want in California. That is not what we want in San Francisco; and the people out there, I assure you . . . are speaking by the thousands and hundreds of thousands . . .

Senator Knowland intervened here to ask a question: "Mr. Mayor . . . you are not contending, are you, that in the event of such a catastrophe that you mention, that the people from Palo Alto on up would all normally flow into... San Francisco when there is a great land connection." Mayor Robinson responded:

I will answer you in this way, Senator Knowland. If you can tell me where the enemy is going to strike, I will tell you where the people will flee. When evacuation comes, they run away from the bullets, not towards them, and if the enemy comes from the South or strikes at the South, which he may logically do down in this area, and if he comes up that way, they are going to run to the bottleneck.

30. San Francisco Chronicle, July 3, 1949; Oakland Tribune, July 7, 1949.

31. Oakland Tribune, July 8, 1949.

32. United States Senate, Committee on Armed Services, Hearings: Easement for Construction of Toll Crossing of San Francisco Bay (July 8, 1949), 96-99. 
A few weeks later San Francisco was vindicated; Secretary of Defense Louis Johnson affirmed the unequivocal opposition of the national military establishment to a parallel bridge. ${ }^{33}$ The Senate turned down Knowland's bill to grant an easement over federal property after Johnson spoke. The Oakland Tribune editorialized a call to continue the fight for a parallel bridge, adding, "The unsubstantiated statement of a 'military preference' is being used in an effort to prohibit consideration of the crossing problem from the only proper standpoint, the best interests of the people who must cross the Bay." 34

By the end of 1949 the bridge controversy had produced a stalemate. The parallel bridge was apparently blocked. However, there were as yet no means available to build a southern crossing. BAC went back to work to find an acceptable regional program.

The perils of consensus-building (1949-1953). In October 1949, the Bay Area Council recommended a forty-five million dollar program to improve the Bay Bridge and build additional approaches. Ralph Tudor approved, agreeing that the improvements would provide some temporary relief and improve safety on the existing structure. BAC followed this minimum program a year later with a Master Plan of Bay Toll Crossings, which included northern and southern bridges across the bay (though not in the same locations as current proposals). BAC patiently worked to unite the region behind its short-term and long-term plans, eventually cvercoming Mayor Robinson's opposition, which was based on a threat he perceived to the financial viability of the southern crossing. Alameda Senator Breed then introduced legislation during the 1951 session to accomplish the improvement program. ${ }^{35}$

The Breed bill authorized CTBA to continue to collect tolls to finance construction of additional approaches and improvements to the Bay Bridge. The amount of money spent on the additions was to be the same on both sides of the bay. In addition, the bill authorized studies to bring plans for the southern crossing up to par with the work already done by DPW on the parallel bridge. ${ }^{36}$ However, as the Breed bill wound its way through the Senate, a new element was interjected into the Bay Area bridge question. The field of competition broadened as senators from the other northern California counties, concerned about the relation of bridge project financing to the state highway fund, decided it was time the Bay Area settled an old debt.

33. San Francisco Chronicle, July 22, 1949.

34. Oakland Tribune, July 22, 1949, editorial.

35. San Francisco Examiner, November 1, 1949; San Francisco Chronicle, November 1, 1949; SBTC, Alterations and Approaches to the San Francisco-Oakland Bay Bridge as Suggested by San Francisco Bay Area Council, 1949, n.p; San Francisco Bay Area Council, "Chronological History: Additional Crossings of San Francisco Bay," November 2, 1951. In Earl Warren Papers, Box 311, Division of Highways-Bridges, 7-12/51. California State Archives, Sacramento.

36. California Senate, Bills, Senate Bill 451, 1951. 
The original legislation provided that the monies advanced to build the approaches be repaid to the state highway system when bridge bonds were retired. The Breed bill provided for this repayment. However, Senator George Hatfield of Merced County, supported by his associates from the northern counties, wanted any new issue of bonds to include funds to repay all the money spent to operate, insure, and maintain the bridge all these years. Moreover, the Hatfield group wanted the bill to provide that such expenses in the future be borne out of tolls rather than by state highway monies. The Hatfield contingent wanted highways for their constituents; they didn't see any reason why their new road funds should be decreased any longer to support Bay Area bridges.

Senator Breed secured amendments to his bill accommodating Hatfield. San Francisco, though, was upset by this turn of events. San Francisco Senator O'Gara sought further amendments eliminating the repayment of operating, insurance, and maintenance expenses. When these failed O'Gara appealed to the Assembly to bottle up the bill until more hearings could be held. The Assembly went along with O'Gara and killed the Breed bill. San Francisco feared these additional expenses would threaten southern crossing financing. BAC went back to work rounding up support. ${ }^{37}$

Mayor Robinson held a meeting with Oakland Mayor Clifford Rishell, the Oakland Chamber of Commerce president, and a few technicians; this group worked out a proposal which they planned to take directly to CTBA. They were hoping that legislative action would not be necessary so that the conflict that broke out during the 1951 session could be bypassed. This strategem failed, however. CTBA refused to proceed in the face of opposition from the northern counties. Since San Francisco wouldn't accept the demands of the Hatfield group, the state legislature refused to authorize CTBA action on BAC's proposed additions/improvements program. ${ }^{38}$

It was now three years since the Bay Area Council first proposed fixing up the Bay Bridge; the consensus-building program hadn't gotten very far. Mayor Robinson decided it was time for bold action. With the support of Marvin Lewis, Mayor Robinson announced in late November, 1952, that he had "come to the conclusion that the impasse with reference to the building of additional Bay crossings must be terminated." The mayor and Marvin Lewis now supported "simultaneous" construction of two additional bridges, one north and one south of the existing one. San Francisco should decide where the terminals would be on its side; the East Bay cities should do likewise. Robinson noted the Bridge Authority had al-

37. CTBA, Transcript of Meeting, November 27, 1951.

38. CTBA, Transcript of Meeting, November 27, 1951; San Francisco Bay Area Council, Memorandum of Meeting with Mayor Elmer Robinson re: San Francisco-Oakland Bay Bridge, August 3, 1951. In Earl Warren Papers, Box 311, Division of Highways-Bridges, 7$12 / 51$. 
ready determined that both additional crossings were necessary. $\mathrm{He}$ stated that he was satisfied there wouldn't be any problem in financing construction of both projects simultaneously. ${ }^{39}$

The Bay Crossings Committee of East Bay Communities, led by the Oakland Chamber of Commerce, applauded this statesmanlike behavior by San Francisco's mayor. The committee resolved its approval of the simultaneous construction proposal and urged immediate action to implement the program. BAC informed the governor of the new initiative. ${ }^{40}$ This new-found optimism did not, however, long survive.

In early December DPW Director Frank Durkee informed Governor Warren of a conversation he had had with Mr. John Inglis, of the Blyth and Company investment banking firm. In a confidential memo Durkee told Warren that "Mr. Inglis volunteered the statement that, in his view, there might be considerable difficulty in financing, under existing conditions, two additional crossings of San Francisco Bay if the crossings were to be undertaken simultaneously." Inglis felt that sufficient revenue bonds to finance simultaneous construction could not be absorbed by the money markets. Durkee wrote that he didn't know if Inglis' views accurately reflected those of other bond houses, but the DPW director reminded the governor that, "as you know, Mr. Inglis has been interested in practically every issue of revenue bonds heretofore put out by the California Toll Bridge Authority." 41

Just before Christmas San Mateo County Assemblyman Richard Dolwig, a southern crossing champion, conducted a hearing about this new proposal for simultaneous construction. State Legislative Auditor Robert Stelmack told the hearing that investment houses had stated that revenue bond financing for simultaneous construction could not be secured..$^{42}$

Assemblyman Dolwig, however, seized the initiative during the 1953 state legislative session. He drafted a bill that placed a southern crossing at the top of the Bay Area infrastructural agenda, at least as far the state was concerned. The 1953 Dolwig Act provided that tolls should be continued on the Bay Bridge even after all bonds were paid off, and that all surplus revenues accruing therefrom were to be used to finance a southern crossing of San Francisco Bay. A set of approaches and terminals on both sides of the bay were included as parts of the project. CTBA was

39. Office of the Mayor of San Francisco, Statement of Mayor Elmer E. Robinson, Reference Bay Bridges, November 20, 1952. In Earl Warren Papers, Box 311, Division of Highways-Bridges, 9-12/52.

40. Bay Crossing Committee of East Bay Communities. Resolution, November 26, 1952. In Earl Warren Papers. Box 311, Division of Highways-Bridges, 9-12/52; San Francisco Bay Area Council, Frank March Memorandum to the San Francisco Bay Area Council. December 3, 1952. In Earl Warren Papers, Box 311, Division of Highways-Bridges, 9-12/52.

41. F. Durkee, Memorandum to Earl Warren. December 3, 1952. In Earl Warren Papers. Box 311, Division of Highways-Bridges, 9-12/52.

42. B. Booker, Report to J. Fleming on Meetings of State Assembly Subcommittee on Bay Area Problems. December 22, 1952. In Earl Warren Papers. Box 311, Division of HighwaysBridges, 9-12/52. 
instructed to take all necessary steps including securing necessary federal legislation and permits to build the southern crossing. Dolwig was sure to include the conditions requested by Senator Hatfield and his associates: the state highway fund would be repaid for historic Bay Bridge expenses, including maintenance, insurance, and operating costs; and all such future costs would be paid from tolls. ${ }^{43}$

The state legislature had finally resolved the controversy, in a manner that reflected the strength of the alliance Dolwig had been able to construct. However, as in 1949 , a battle had been won, but the war was not yet over. Oakland leaders felt betrayed by their San Francisco counterparts because the San Francisco leadership had abandoned the idea of simultaneous construction. Moreover, Oakland still had a few Washington, D.C. options available. The national government had to give its permission to continue toll collection on the Bay Bridge to help finance additional construction. Senator William Knowland was said to be seeking an amendment to the necessary federal legislation that would would guarantee building a parallel bridge after the southern crossing was finished.

In 1949, when CTBA wanted to build a parallel bridge, Oakland leaders told the Congress this was a purely local matter. San Francisco leaders now said the same thing. The conflict between the cities, however, was as obvious in 1953 as it had been in 1949. The House Public Works Committee chairman noted the bitterness; he offered the Bay Area leaders the use of his conference room to achieve consensus rather than come before the Congress disunited. The chairman pointed out one of the well-known rules of legislative procedure: a higher level of government was loathe to enter into conflicts at a lower level. It was far preferable that local people work out their differences without outside intervention.

Oakland Mayor Rishell angrily told the House Committee that there had already been two agreements with San Francisco, but San Francisco had run out on them. Oakland was now supporting an amendment offered by an Alameda County representative that would specify in the federal legislation that a parallel bridge be built following the southern crossing. The House, however, was obviously reluctant to write something so specific when the state legislature had declined to do so. ${ }^{44}$ Congress passed legislation authorizing continued toll collection but refused to include a provision mandating parallel bridge construction. ${ }^{45}$ The next step was a permit from the army to cross navigable waters. It looked like smooth sailing for the southern crossing.

The dynamics of political and military claims: Part II (1953-1956). In August, 1953, the navy shocked the celebrating southern crossing propo-

43. California, Statutes, Chapter 1056, 1953.

44. United States House of Representatives, Committee on Public Works, Hearings, June 23, 1953.

45. United States Congress, Eighty-third Congress, First Session, Public Law 154, Chapter 248, 1953. 
nents by opposing DPW's request to the army for a permit. The navy gave a flat "No" to the West Bay location specified in the Dolwig Act because the navy had plans for possible seaplane development in the area. These plans were so new and so secret that the Bay Area navy official who made public the opposition did not know any of the details. This was a decision taken at the top level of the navy command in Washington; the local navy people were as surprised as everyone else. The San Francisco Examiner editorially charged that "political" considerations motivated the navy action. Moreover, just as the Tribune had argued that military concerns were inappropriately being put forward in 1949, the Examiner now felt the navy had gotten out of line: ${ }^{46}$

[When] the Navy attempts to grab off a vast expanse of the Bay waters for some possible future need, when the Navy springs its demands as a complete and patently intentional surprise that prevents city officials from cross-examining to develop the facts, when the Navy would so casually kill a multimillion dollar civilian bridge project, we say the Navy has overreached itself.

San Francisco mobilized to wring concessions for the navy. Under intense pressure the navy bent sufficiently to allow a modified southern crossing project. The bends, however, increased construction costs and presented significant engineering difficulties. During 1954, though, DPW was able to secure the necessary army permits; the state engineers then settled into the detailed design work necessary to develop a financing and construction program. ${ }^{47}$

Seven years after the Joint Army-Navy Board had proposed it, a southern crossing was finally at the top of the Bay Area transportation agenda. The 1953 Dolwig Act declared the southern crossing to be the next transbay transport facility. The crossing was granted exclusive access to surplus Bay Bridge revenues, thereby assuring a source of income for the project.

The success of the southern crossing proponents would be extremely consequential for the future history of the regional rail rapid transit movement. In the Joint Army-Navy Board plan the crossing and regional rapid transit were complementary elements in a comprehensive solution to Bay Area transportation needs. These elements would, however, increasingly come into conflict with each other. In addition, the final defeat of the parallel bridge changed the character of the Oakland leadership's participation in the regional rapid transit movement. Oakland had successfully parried San Francisco's thrusts toward regional rapid transit since Marvin Lewis seized the initiative in 1948. Such a system appeared to Oakland as an obvious effort to penetrate rapidly growing peripheral areas in the East Bay, thereby consolidating downtown San Francisco's leading position

46. San Francisco Examiner, August 20, 1953, editorial.

47. SBTC, Progress Report, Southern Crossing, 1954, n.p; San Francisco Examiner, August 25, 1953, September 2, 1953; San Francisco Chronicle, August 26, 1953. 
and denying the Oakland central business district dominion over its residential hinterlands. They now became far more interested in the movement's progress and possibilities than they previously had been. ${ }^{48}$

The significance of access to project finance in the infrastructure planning process (1955-1958). In December 1955, Chief Engineer Norman C. Raab of the Division of San Francisco Bay Toll Crossings reported on the progress of southern crossing work. Raab found the crossing feasible from an engineering standpoint, though difficult. It would also be extremely expensive. Based on traffic and earnings projections which did not assume either regional rapid transit or changes in the Bay Bridge, Raab estimated that $\$ 180$ million worth of revenue bonds could be sold with the toll remaining at the current twenty-five cents. This amount would be sufficient to construct only a "minimum" crossing; there wouldn't be any approaches to the crossing in San Francisco and only minimal approaches in the East Bay. An increase in the toll to thirty-five cents would be necessary to raise the $\$ 250$ million necessary to build the entire project as outlined in the 1953 Dolwig Act. ${ }^{49}$ After a decade of bitter conflict and with victory seemingly at hand, this was very disheartening news to San Francisco, San Mateo, and southern Alameda County activists.

In early 1956 representatives from these areas began working on proposals to make the southern crossing project financially viable. They voluntarily accepted an important constraint: bridge tolls would remain at their current twenty-five cent level. By April Dolwig was able to secure support from the state legislature for two critical amendments to his 1953 Act which would enable construction of the "minimum" crossing without touching the twenty-five cent toll. Moreover, George Burpee, leading figure in the consulting firm of Coverdale and Colpitts, said the $\$ 180$ million first-stage construction program could definitely be financed without raising the toll. The minimum southern crossing project thus had the blessings of the firm that had been doing financial studies for Bay Area bridges since the first such projects. Dolwig voiced great optimism that no more obstacles appeared in the way. CTBA was ready to proceed with a bond issue. ${ }^{50}$

The path of the rail rapid transit movement, however, now began to intersect that of the southern crossing. The Optimum Plan recommended by the consultants to the Bay Area Rapid Transit Commission (BARTC), published in January 1956, called for the construction of an extensive rail rapid transit system in the East and West Bays, and an underwater tube connecting the San Francisco and Oakland central business districts. The

48. S. Adler, The Political Economy of Transit in the San Francisco Bay Area, 1945-1963. 49. SBTC, Report to the Department of Public Works on the Southern Crossing of San Francisco Bay, 1955, n.p.

50. San Francisco Chronicle, March 3, 1956, San Francisco Examiner, April 3, 1956; California, Statutes, Chapter 67, First Extraordinary Session, 1956. 
tube was the key element cementing an alliance of the two downtowns. It would allow East Bay trains to converge in central Oakland before crossing the bay without seriously extending travel time to downtown San Francisco. This design would enable San Francisco and Oakland to co-exist peacefully, jointly pursuing their aspirations in the East Bay. Moreover, the consultants argued that the combination of a tube and a reconstructed Bay Bridge-which the tube would make possible-would eliminate the need for a southern crossing for at least fifteen years. The transit movement leadership began to express interest in the surplus Bay Bridge toll revenues currently reserved for the southern crossing. ${ }^{51}$

In a March 1956 news story, the San Francisco Chronicle quoted Bay Area Rapid Transit Commission Chairman Alan Browne as calling for postponement of the southern crossing because the crossing might jeopardize the regional rapid transit plan. Browne pointed to the suggestion made by Stanford Research Institute for using bridge tolls for transit. $\mathrm{He}$ also noted the Optimum Plan would make a southern crossing unnecessary for the time being. ${ }^{52}$

A few days later the Chronicle began to reconsider its historic support for an additional motor vehicle facility. An editorial noted Alan Browne's position that both a southern crossing and rapid transit were not financially possible. Browne was quoted as arguing that there were "financial relationships between the ... rapid transit plan and the . . crossing plan that tend to make them mutually exclusive." The Chronicle took special notice of Browne's comment that he didn't "think we should risk everything for one more crossing of the Bay. . . . What is more important for the future of the area, moving cars or people? I think moving people is more important." 53

Legislation sponsored by BARTC was introduced at the state capitol which would exempt a rapid transit tube from the prohibition on construction of a bay crossing within ten miles of an existing toll bridge on which bonds were still outstanding. San Francisco officials responded to the measure with extreme ambivalence, as did Richard Dolwig. San Franciscans worried that support for the tube at this time would jeopardize the southern crossing. Dolwig was similarly concerned. However, San Francisco also wanted regional rapid transit. After lengthy and agonizing discussions, official San Francisco adopted the position that it would support legislation exempting a transit tube from the ten-mile prohibition only if investment bankers gave assurances this would not jeopardize southern crossing financing. Mayor George Christopher pointed out that the bridge was still the city's top transportation priority. ${ }^{54}$

Dolwig announced that he had received such assurances from the in-

51. S. Adler, The Political Economy of Transit in the San Francisco Bay Area, 1945-1963.

52. San Francisco Chronicle, March 16, 1956.

53. San Francisco Chronicle, March 19, 1956, editorial.

54. San Francisco Chronicle, March 13, 1956, March 17, 1956. 
vestment community shortly thereafter, that there wouldn't be any conflict. The investment people were primarily concerned that the legislation enabling transit tube construction be passed before the crossing was financed, so that no changes would be made in midstream. These assurances were apparently sufficient for Dolwig and San Francisco; the transit bill was passed at the end of April, just after Dolwig's own amendments to the southern crossing legislation were enacted. ${ }^{55}$

However, in December 1956, CTBA was informed by its financial consultants, Smith, Barney and Company, that revenue bonds for a minimum southern crossing project secured by a twenty-five cent toll would not be saleable in the money markets at that time. Smith, Barney concluded that "the revenue bond financing necessary to finance its [minimum southern crossing] construction would not comply with all of the generally accepted investment standards for such securities and ... must, therefore, be considered marginal as to financial feasibility." 56

This was, of course, an interesting and consequential pronouncement. George Burpee of Coverdale and Colpitts had said just eight months previously that the minimum crossing project was financially feasible. The critical role of members of the financial community in the public works planning process seems particularly evident at this point. Bank of America and Blyth and Company were the leading commercial and investment banking firms in the region. They had always been closely involved with CTBA financing efforts. Alan Browne, chairman of the Bay Area Rapid Transit Commission, was a Bank of America vice-president in charge of municipal bonds. Arthur Dolan, another leading BARTC member, was an official in the investment banking firm of Blyth and Company. Both men were underwater tube supporters. Smith, Barney and Company would serve as financial advisors to the Bay Area Rapid Transit District. These representatives of the San Francisco financial district were expressing their preference for transit rather than another bridge crossing in a most effective manner, reflecting their general as well as place-specific interest in the benefits the proposed downtown/radial rail rapid transit system would confer. ${ }^{57}$

Financial access had serious consequences for downtown San Francisco, however. Having lost a project they had fought long and hard to secure, the peninsula counties of San Mateo and Santa Clara severed their ties to the regional transit movement. Santa Clara refused even to join the Bay Area Rapid Transit District (BARTD) created by the state legislature in 1957. Exercising an option included in the district-creation law at its insistence, San Mateo withdrew a few years later. When San Mateo withdrew, Marin County was forced to join the exodus, since the property

55. San Francisco Chronicle, March 15, 1956; California, Statutes, Chapter 40, First Extraordinary Session, 1956.

56. CTBA, Transcript of Meeting, December 12, 1956.

57. S. Adler, The Political Economy of Transit in the San Francisco Bay Area, 1945-1963. 
values of the shrunken district would not be able to support the construction of an expensive Golden Gate crossing. A severely truncated BART system limped onto the ballot in 1962, after barely surviving another challenge in Contra Costa County.

Just as Oakland had argued before the defeat of the parallel bridge, local coalitions in the peninsula counties opposed the regional transit project as an instance of the imperial aspirations of downtown San Francisco. San Mateo and Santa Clara sought transport infrastructure that would facilitate their aspirations for autonomous economic development. On their behalf, as well as that of southern Alameda County, during the same 1957 session the legislature appropriated money for studies leading to plans and a bond issue to at least double the capacity of the existing San Mateo-Hayward Bridge, seventeen miles south of the Bay Bridge. San Mateo and Santa Clara would each create their own transit districts as well. 58

Bay Toll Crossings Division Engineer Norman Raab was now directed to study the reconstruction of the Bay Bridge. His work was financed with a $\$ 50,000$ emergency appropriation made possible by the state legislature. The legislators noted CTBA must be in a position to commence reconstruction work without delay if and when Key Systems trains, which had been running across the Bridge Railway since 1939, were abandoned. Key System was currently before the California Public Utilities Commission seeking permission to substitute buses for trains on its transbay routes. Raab reported in March 1957 that the Bay Bridge could be reconstructed so as to increase its traffic carrying capacity by twenty-five to thirty-five percent. Raab proposed paving the Bridge Railways lanes and establishing one way traffic on each deck. He estimated the cost of reconstruction at thirty-five million dollars. Soon thereafter, the Utilities Commission granted Key System permission to abandon the Bridge Railway trains and substitute buses. In April the state legislature took up a bill enabling CTBA to reconstruct the Bay Bridge for general traffic. The bill provided that Bay Bridge revenues currently available and available through July 1 , 1961 could be used to finance reconstruction. ${ }^{59}$

In early April 1958, DPW reported to CTBA that investment bankers had indicated once again that the southern crossing was not a safe and attractive investment for private capital. DPW recommended that construction was neither feasible nor in the public interest. CTBA agreed. ${ }^{60}$ Just a few weeks later the Bay Area Rapid Transit District requested CTBA to consider building a rapid transit tube as its next bay crossing,

58. S. Adler, The Political Economy of Transit in the San Francisco Bay Area, 19451963, California, Statutes, Chapter 2416, 1957.

59. SBTC, Reconstruction of the San Francisco-Oakland Bay Bridge, 1957, n.p; California Public Utilities Commission, Decisions, Number 54669, 1957; California, Senate, Bills, Senate Bill 1643, 1957.

60. CTBA, Transcript of Meeting, April 3, 1958. 
and to use surplus Bay Bridge toll revenues to finance its construction. ${ }^{61}$ In 1959 the state legislature authorized CTBA to do so.

\section{Conclusion}

In his foreword to Robert Moses' book about public works, Raymond Moley wrote:

From the pyramids of Egypt, to the rebuilding of Rome after Nero's fire, to the creation of the great medieval cathedrals and the reconstruction of Paris by Baron Haussmann, all great public works have been somehow associated with autocratic power. For pure democracy has neither the imagination, nor the energy, nor the disciplined mentality to create major improvements. ${ }^{62}$

Regardless of what he meant by "pure democracy," Moley is clearly wrong regarding its incapacities. Imagination, energy, and a disciplined mentality have never been lacking. Rather, the abundance of these factors, generated by the structural fact of spatial competition and sustained by the responsiveness of legislative bodies to local investor coalitions, produces a strong tendency to stalemate the construction of large-scale infrastructure projects. The Bay Area case illuminates ways in which stalemate may at least partially be transcended.

The Bay Area Council labored mightily to build consensus regarding transport investment in the region. BAC claimed to articulate the interests of the region as a whole regarding infrastructure concerns. Yet competitive localities repeatedly undermined BAC efforts to unite the region behind an investment program. When BAC sought to assemble a package of projects designed to appeal to numerous competitors, the perception that the package included elements that would concentrate benefits disrupted consensus. Local coalitions continuously pursued governmental opportunities that would defend and advance their individual interests outside the BAC-organized consensus-building process.

However, while BAC failed to build consensus, disaggregation was an essential aspect of overcoming the stalemate. The state legislature, always respectful of local autonomy, permitted the peninsula counties to withdraw from the regional rapid transit project and supported their quest for locally oriented transport facilities. As a result, a variety of smaller-scale projects serving several subregional alliances became feasible.

At no point did political or military priority claims silence opposition. Whether argued by local project sponsors or military branches, all such claims on behalf of particular projects were immediately involved in the location conflict, and, therefore, suspect. Since the early history of this

61. CTBA, Transcript of Meeting, April 30, 1958.

62. R. Moley, "Foreword," in R. Moses, Public Works: A Dangerous Trade (New York: McGraw-Hill, 1970), xi. 
controversy coincided with the most intense period of cold war hostility as well as the Korean War, though, political and military considerations carried weight. San Francisco and Oakland both asserted such claims to defend against each other's initiatives. However, since large-scale unemployment was not an issue, nor was the country immediately subject to threat from without, political and military priority claims could not themselves provide a way of overcoming stalemate.

Access to project finance was decisive. However, even the financial gatekeepers were constrained by competing local coalitions. The California Toll Bridge Authority sought to build only those motor vehicle facilities they believed would be profitable, and to eschew investment in transit. The financiers leading the regional rapid transit movement were, however, able to steer the CTBA in the direction the transit activists wished to go. The financial disabilities of transit did force the movement to seek governmental subsidy, thereby opening up the project decision process to opponents and to popular electoral participation. This resulted in a much scaled-down project and relatively favorable terms for organized transit labor during the transition from a private to a governmental industry. 